\title{
Recorregut de recerca geològica i mineralògica per la comarca del Pallars Sobirà: des del Coll de Triador, a Entremonts, al Pas de Mainera, a la Portella i alColl d’Eixol
}

Josep Maria Mata-Perelló

Joaquim Sanz Balagué

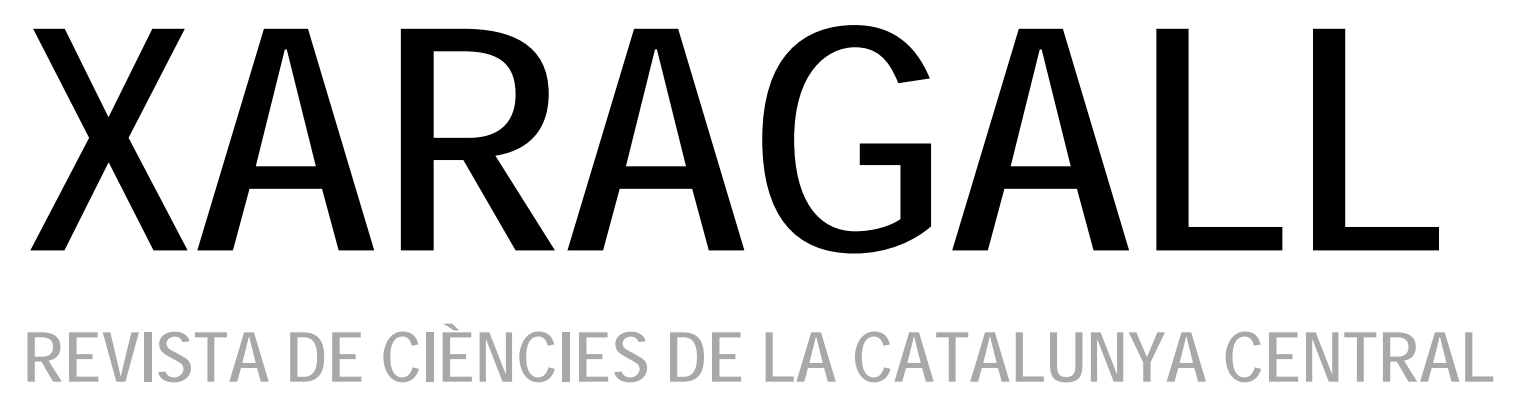

ก. 9

SETEMBRE 2014 


\title{
RECORREGUT DE RECERCA GEOLÒGICA I MINERALÒGICA PER LA COMARCA DEL PALLARS SOBIRÀ: DES DEL COLL DE TRIADOR, A ENTREMONTS, AL PAS DE MAINERA, A LA PORTELLA I ALCCOLL D’EIXOL
}

\author{
Josep Maria Mata-Perelló \\ Museu de geologia Valentí Masachs, Escola Politècnica Superior d'Enginyeria de Manresa \\ (EPSEM), Universitat Politècnica de Catalunya · BarcelonaTech (UPC), 08272 Manresa, Spain
}

\section{Joaquim Sanz Balagué}

Departament d'Enginyeria Minera i Recursos Naturals (EMRN), Escola Politècnica Superior d'Enginyeria de Manresa (EPSEM), Universitat Politècnica de Catalunya . BarcelonaTech (UPC), 08272 Manresa, Spain

Paraules clau: Sistema pirinenc, Zona Axial Pirinenca, materials paleozoics, Patrimoni miner

\section{Resum}

Itinerari realitzat el 12 d'octubre de 2013. En aquesta ocasió, la totalitat del recorregut de l'itinerari discorrerà íntegrament pel Sistema Pirinenc. Això si, discorrerà sempre el seu recorregut per la Zona Axial Pirinenca (en concret per la denominada Unitat dels Apilaments de la Zona Axial).

Així, tots els materials que anirem trobant en aquest recorregut seran paleozoics, fonamentalment de l'Ordovicià. Tot i això, molt sovint aquests materials els trobarem recoberts per sediments del Pleistocè i de l'Holocè, que molt sovint corresponen als sediments detrítics d'origen glacial: és a dir a les morrenes. També corresponen als sediments fluvials de la Noguera Pallaresa i dels seus diferents afluents.

Per altra banda, el recorregut de l'itinerari discorrerà íntegrament per una sola comarca, concretament per la del Pallars Sobirà, de la Regió de Tremp (o de Tremp-Seu d'Urgell). Al mateix temps, part del recorregut transitarà pel Parc Nacional d'Aigües Tortes, especialment pels voltants del Montsent de Pallars i del Montorroio. 


\section{Objectius fonamentals}

Es centraran en els aspectes geològics, geomorfològics i mineralògics que apuntarem a continuació:

1. Observació de l'estructura del sector corresponent als Apilaments Antiformes de la Zona Axial Pirinenca, per entre la qual discorrerà la totalitat del recorregut de l’itinerari.

2. Observació dels materials paleozoics de la denominada Unitat dels Apilaments de la Zona Axial Pirinenca. Aquests materials pertanyen, segons als llocs al Cambro-Ordovicià, Ordovicià, Silurià i Devonià. i a l'Ordovicià. Tanmateix, trobarem afloraments de roques granítiques, les quals pertanyen al Carbonífer i al Pèrmic, formades durant l'Orogènia Hercínica.

3. Observació dels diferents indrets relacionats amb el Patrimoni Geològic, que anirem trobant al llarg del present itinerari. En concret, cal fer esment del relacionats amb el Patrimoni Geomorfològic, relacionat amb la morfologia glacial.

4. Observació de les mineralitzacions que trobem al llarg del recorregut de l'itinerari, com es el cas de les següents:

4A) de les mineralitzacions associades a skarn, que trobarem prop d’Entremonts, amb la presencia de TREMOLITA (amiant).

4B) si s'escau, de les mineralitzacions de rebliment de cavitats d'origen kàrstic, que trobarem al Montorroio, entre els materials del Devonià

5. Observació de les antigues explotacions mineres, relacionades amb la primera de les mineralitzacions anteriors, veient el seu impacte.

6. Observació, si s'escau del Patrimoni Geològic i Miner, relacionat amb les mineralitzacions i amb les explotacions mineres.

\section{Antecedents}

Pel que fa al recorregut d'aquest itinerari, no coneixem cap antecedent pel que fa a total recorregut. Així, es podria considerar com una primícia. Tot i així, hi ha un itinerari entre Espot i els Llacs de Mainera, al Ilibre de MARTINEZ et altri 2013. També farem esment d'uns itineraris propers nostres: Mata-Perelló (2013a, b i c), així d'un que és precedent de l'actual (amb el que coincideix en bona part): Mata-Perelló (2013d)

Pel que fa a les mineralitzacions que veurem en aquest itinerari, cal dir que també ja estat prèviament descrites per nosaltres en Mata-Perelló (1991). Així, com Mata-Perelló i Sanz Balagué (1993).

I pel que fa a l'estructura geològica, ens remetem al treball de Riba et altri (1976), i al de Guimerà et altri (1992). En ambdós, es fa referència a l'estructura geològica dels Països Catalans. Per altra banda, cal fer especial menció del recent treball de Martínez et altri 2013. 
Finalment, cal dir que tots aquests treballs, es trobaran relacionats, per estricte ordre alfabètic, dintre de l'apartat dedicat a les REFERÈNCIES BIBLIOGRÀFIQUES, al qual es remetem, pel que s'escaigui.

\section{Recorregut de l'itinerari}

El recorregut del present itinerari s'iniciarà per les immediacions de la població de Llessui, a la vall d'Assua. Des d'aquesta població, caldrà agafar una pista forestal en irregular estat de conservació, per la qual cosa ens caldrà demanar la suficient informació.

Per aquesta pista, arribarem en uns $6 \mathrm{Km}$ al Coll de Triador. Tot i així, si s'escau, es pot arribar fins aquest indret des d'Espui, per un camí en millor estat de conservació (ara per ara, octubre del 2013). De fet el recorregut de l'itinerari s'iniciarà en aquest indret. A partir d'aquest indret, ens caldrà seguir cap al Nord, amb la intenció d'arribar al Barranc d'Entremonts, per on seguirem a peu fins a les antigues Mines d'Amiant.

Després de retornar a la pista, convindrà continuar cap al Nord, per tal d'arribar a la Collada del Clot de Montorroio, per on buscarem la Mina de Manganès, situada per sota del pic del mateix nom.

Després, caldrà seguir de nou cap el Nord, per tal d'arribar a l'aparcament del riu de Mainera, des d'on continuarem a peu, remuntant-lo, amb la finalitat d'arribar fins al Pas de Mainera, per on farem una nova aturada.

I, finalment, ens caldrà continuar cap a Espot, per tal de finalitzar el recorregut a la vall del riu Escrita, per on farem la darrera aturada.

\section{Advertiments previs}

Com en altres recorreguts de RECERCA GEOLÒGICA I MINERALÒGICA... si es disposa del temps suficient, poden efectuar-se passant per totes les parades i filloles. En cas contrari, recomanem prescindir de les anomenades PARADES - CONDICIONALS.

En aquest itinerari, cal tenir força cura del coneixement sobre l'estat de les pistes de muntanya. Així, en aquest cas hi haurà un recorregut per una llarga pista forestal, que uneix Llessui amb Espot, de la qual no en tenim gaire coneixement sobre el seu estat de conservació. Així, ens caldrà buscar la màxima informació possible i anar amb la màxima cura en tot el recorregut.

Per d'altra banda, i com de costum, recomanem tenir el màxim respecte per la natura, tant al llarg d'aquest recorregut, com en qualsevol moment, al marge d'ell. 


\section{Descripció de l'itinerari}

En aquest recorregut hem situat, com ja és habitual en tots els itineraris, una sèrie d'ESTACIONS o de PARADES, que anirem veient a continuació. En cada cas, els hi donarem una denominació que podrà correspondre a algun paratge proper. També indicarem el terme municipal i la comarca on es troba.

Per d'altra banda, en cadascuna de les parades, indicarem entre parèntesi el número del "Mapa Topográfico" (de I'Instituto Grográfico y Catastral de España), a escala 1:50.000, on es troba situada la parada considerada. En aquesta ocasió totes les aturades es realitzaran dintre dels fulls 181 (o d’Esterri d’Àneu) i 214 (o de Sort).

També utilitzarem el full $n^{\circ} 54$ (Vall Fosca, Montsent de Pallars i Vall de Manyanet) del Mapa Topogràfic de Catalunya, a escala 1: 25.000, publicat per l'Institut Cartogràfic de Catalunya.

Així doncs, la relació de les parades ordenades, que constitueixen aquest itinerari, és la següent

\subsection{Parada 1. IMMEDIACIONS DEL COLL DEL TRIADOR, (Espuí i Llessui, termes municipal de la Torre de Cabdella i de Sort, comarques del Pallars Jussà i del Pallars Sobirà, respectivament). (Fulls 214 i 54).}

Des de l'inici del recorregut, haurem pujar cap al Monsent de Pallars, amb la intenció d'arribar fins al Coll de Triador. Aquí farem la primera aturada, tant si hem pujat des de Llessui o des d'Espui.

Ara ens trobem als peus del impressionant Montsent de Pallars, per on afloren els materials del Devonià de la zona dels Apilaments Antiformes de la Zona Axial Pirinenca, per on estem situats. En aquest cas, el pic acabat d'esmentar, forma part d'un encavalcament.

En aquests recorreguts, en bona part del mateix i especialment prop del coll, haurem trobat afloraments dels materials paleozoics del Silurià, els quals molt sovint es troben força replegats, com pujant des d'Espui, a menys de $1 \mathrm{Km}$, abans d'arribar al coll. (fotografia 1). 


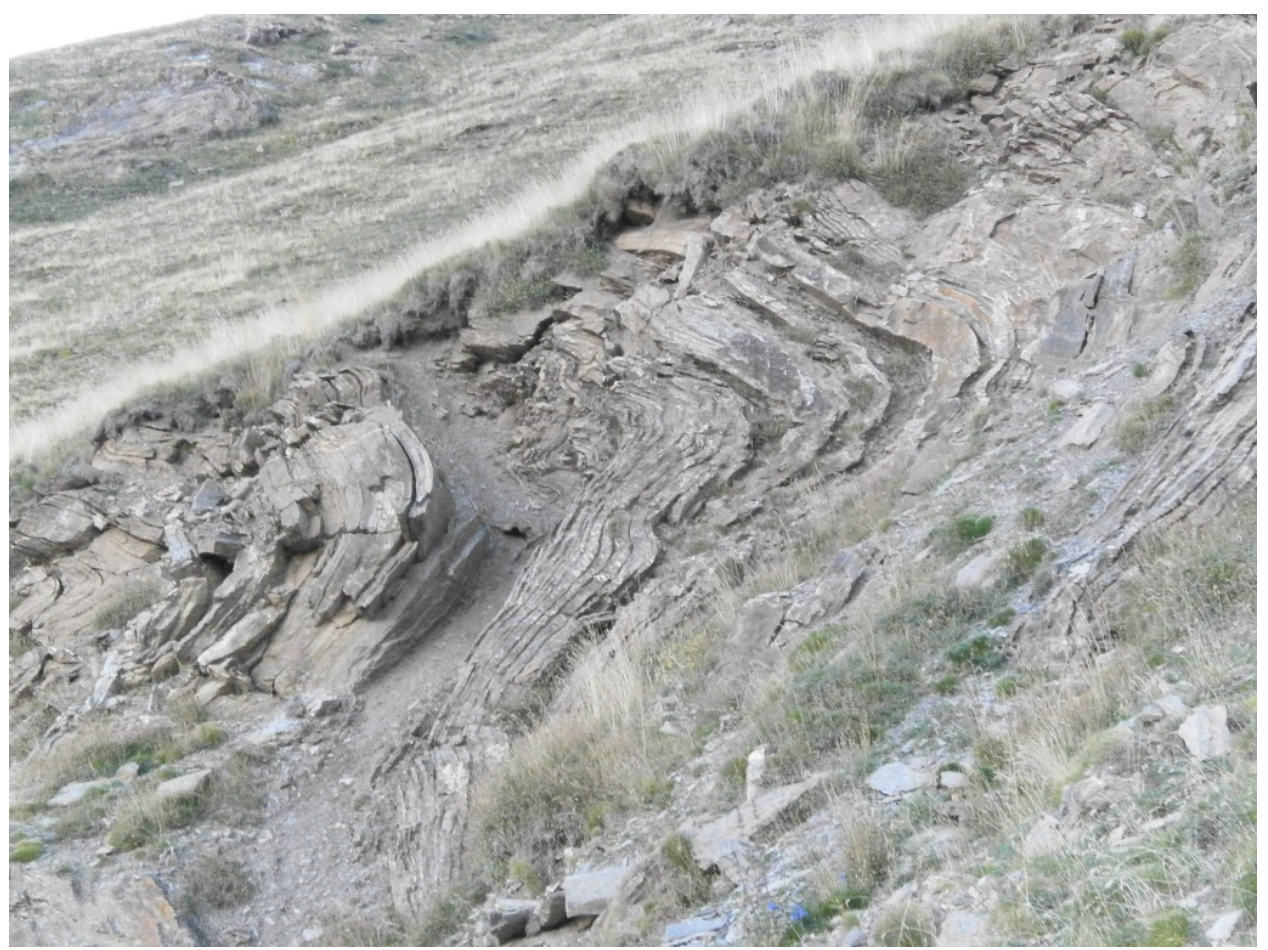

Fotografia 1. Un aspecte dels plecs i replecs entre els matetrials pissarrencs del Siluria. Camí d’Espui al Coll de Triador Setembre 2013

Per altra banda, des d'aquest indret del Coll de Triador, es pot gaudir d'una bona visió, tant dels indrets situats a llevant, cap a la Vall d'Assua (al Pallars Sobirà), com dels situats a ponent, cap a la Vall Fosca (al Pallars Jussà). Així, per arreu, es poden veure uns interessants relleus de morfologia glacial.

Recorregut de recerca geològica i mineralògica per la comarca del Pallars Sobirà: des del Coll de Triador, a Entremonts, al Pas de Mainera, a la Portella i alCcoll d’Eixol 


\subsection{Parada 2 - CONDICIONAL. L'ESTANYESSO O L'ESTANYET, (Llessui, terme municipal de Sort, comarca del Pallars Sobirà). (Fulls 214 i 54).}

Des de la parada anterior, cal continuar per la pista que va conduint cap el Nord, cap a Espot. En arribar a l'Estanyesso, si s'escau, ens caldrà fer una nova aturada. Així, des de l'anterior, haurem efectuat un recorregut proper als $6 \mathrm{Km}$, des de la parada anteriorment realitzada.

En aquest recorregut, hem passat per indrets d'una gran bellesa per la capçalera del Barranc de Pamano; i més endavant, després d'arribar a un collet, per la capçalera del Barranc de Berasti. Finalment, haurem arribat a l'indret on es troba l'Estanyesso (també denominat I'Estanyet, donades les seves dimensions). En aquest indret farem aquesta nova aturada.

Per d'altra banda, haurem trobat afloraments dels materials paleozoics del Silurià i del Devonià, els quals formen part dels Apilaments Antiformes de la Zona Axial Pirinenca, per on estem situats en aquest indret.

En aquest indret hi ha una zona clarament periglacial, amb uns aiguamolls, que formen un petit estany. (fotografía 2). 


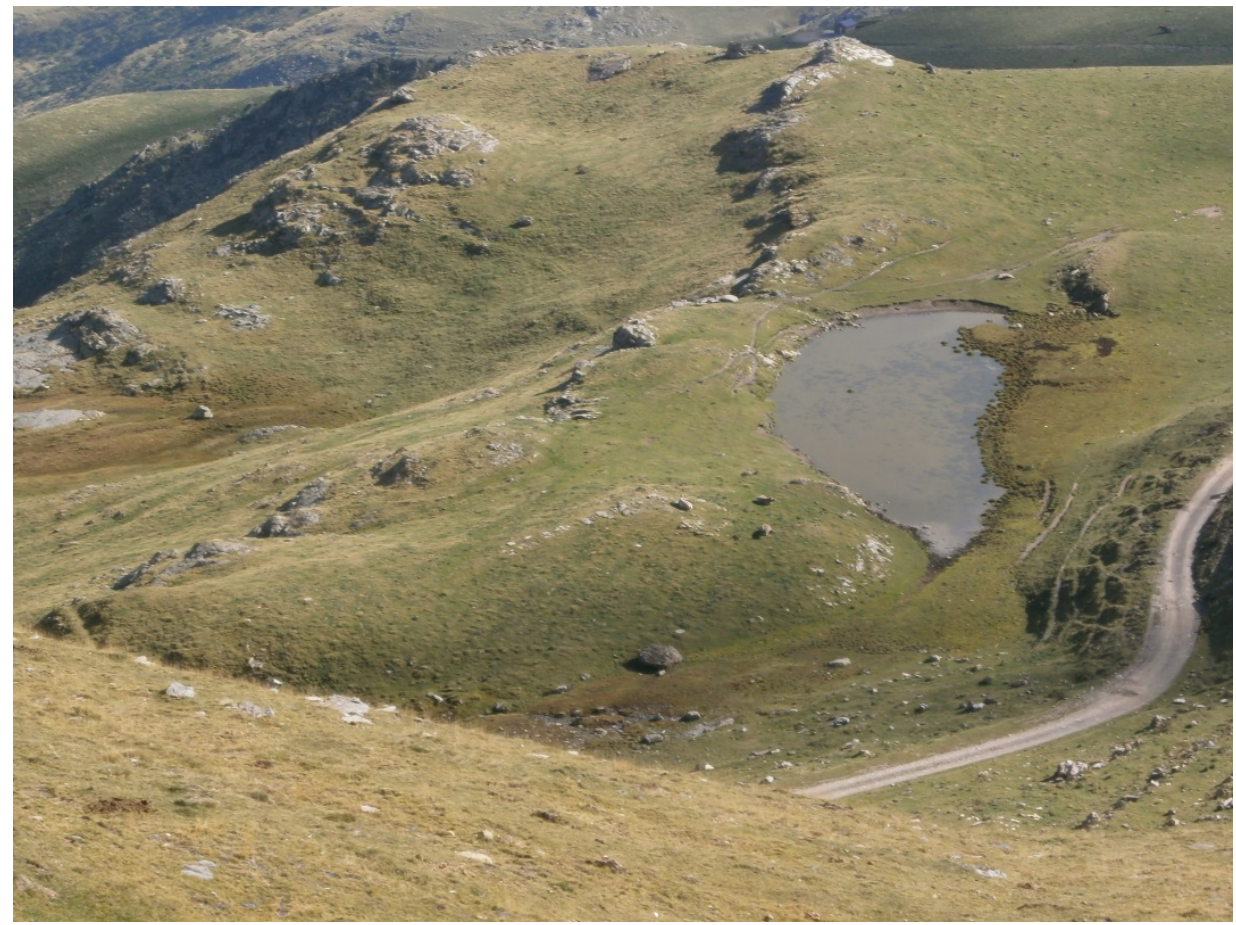

Fotografia 2. L'Estanyesso. Fotografia de l'octubre del 2012

\subsection{Parada3. COMA D'ENTREMONTS, (Llessui, terme municipal de Sort, comarca del Pallars Sobirà). (Fulls 214 i 54).}

Des de la parada anterior, cal continuar el recorregut cap el Nord, per la pista en irregulars condicions, la qual condueix cap a Espot. A molt poca distancia de l'indret anterior, en arribar al Barranc d'Entremonts (a menys de 0’1 km de l'indret anterior), ens convindrà deixar el cotxe, per tal de remuntar el barranc, pujant cap el Circ d'Entremonts per on hi ha la capçalera del barranc. Així, ens anirem apropant cap a l'indret on hi havia la Mina d'Amiant d'Entremonts. En arribar-hi, després d'un ascens d'uns 250 - 300 metres, farem una nova aturada. Tardarem prop de 1 hora en pujar. Però, abans, realitzarem algunes aturades. Aquesta la realitzarem poc abans d'arribar a la Mina d'Amiant, ben visible (pel que fa a la seva escombrera) des d’aquí.

En aquest recorregut, hem continuat trobant afloraments dels materials paleozoics esmentats a les aturades anteriors. Efectivament, per aquest indret hi afloren les roques carbonatades del

Recorregut de recerca geològica i mineralògica per la comarca del Pallars Sobirà: des del Coll de Triador, a Entremonts, al Pas de Mainera, a la Portella i alCcoll d’Eixol 
Devonià, Tanmateix s'observen afloraments dels nivells pissarrencs del Silurià. Uns i altres materials es troben dintre de la Zona Axial Pirinenca.

En aquest recorregut, haurem trobat força replegats els materials paleozoics, tant els del Montsent (situat al Sud), com els del Montorroio (situat al Nord). Alhora els hem vist molt fracturats. (fotografia 3). Cal dir que tot aquest recorregut, l'estem realitzant entre els dos relleus.

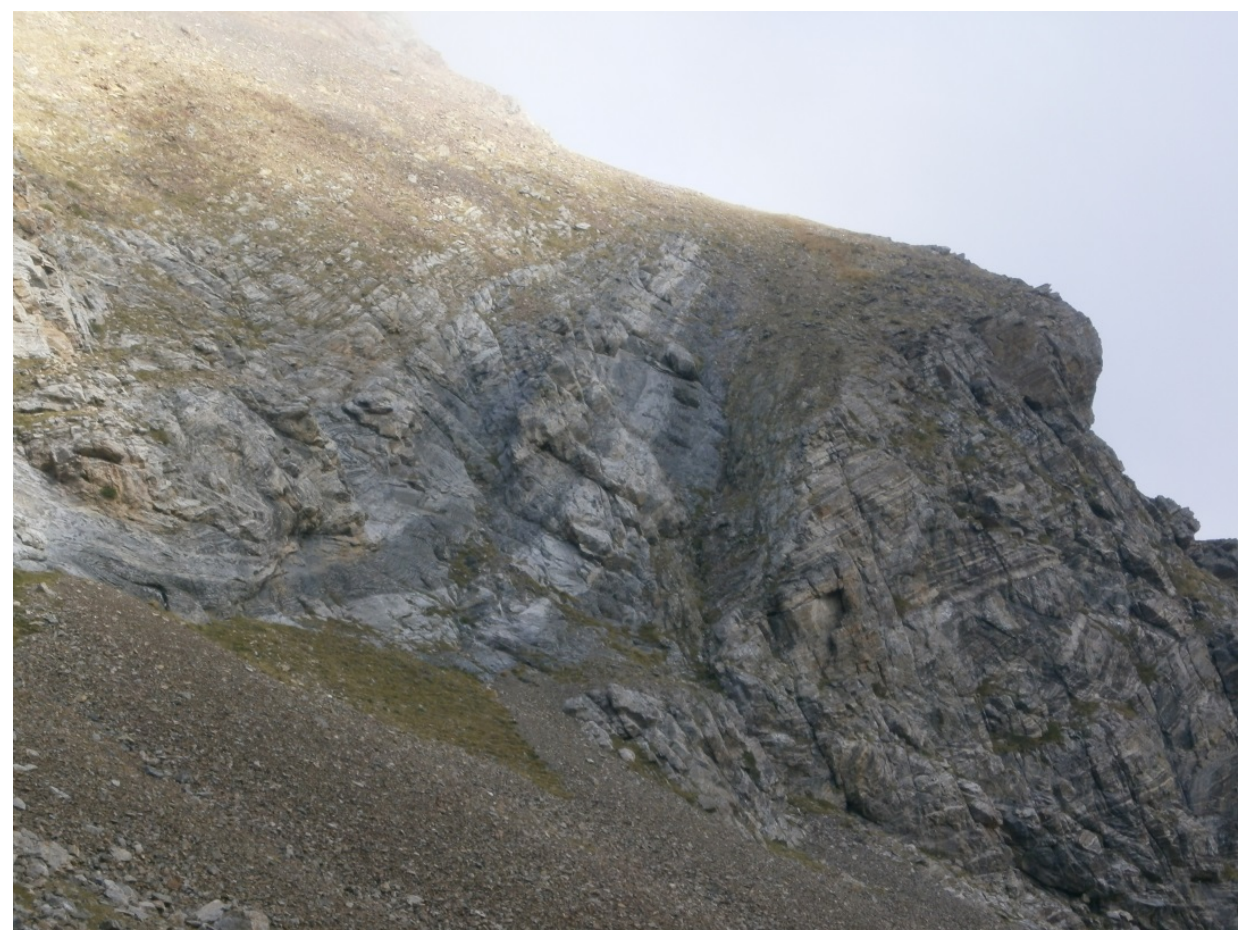

Fotografia 3. Plec i fractura entre els materials del Devonià del sector meridional del Montorroio, per sobre de la Coma d’Entremonts. Fotografia de l'octubre del 2012

A més de la fractura anterior, haurem trobat innumerables plecs entre els materials paleozoics, al llarg de tot aquest recorregut.

Per d'altra banda, en arribar a l'indret de l'aturada, veurem una plana, que correspon a la Coma d'Entremonts. En realitat són dos comes. Corresponen a uns antics llacs d'origen glacial reblerts per sediments del Pleistocè i de l'Holocè. Tot i així, es veu mol clara la seva morfologia. (fotografia 4) 


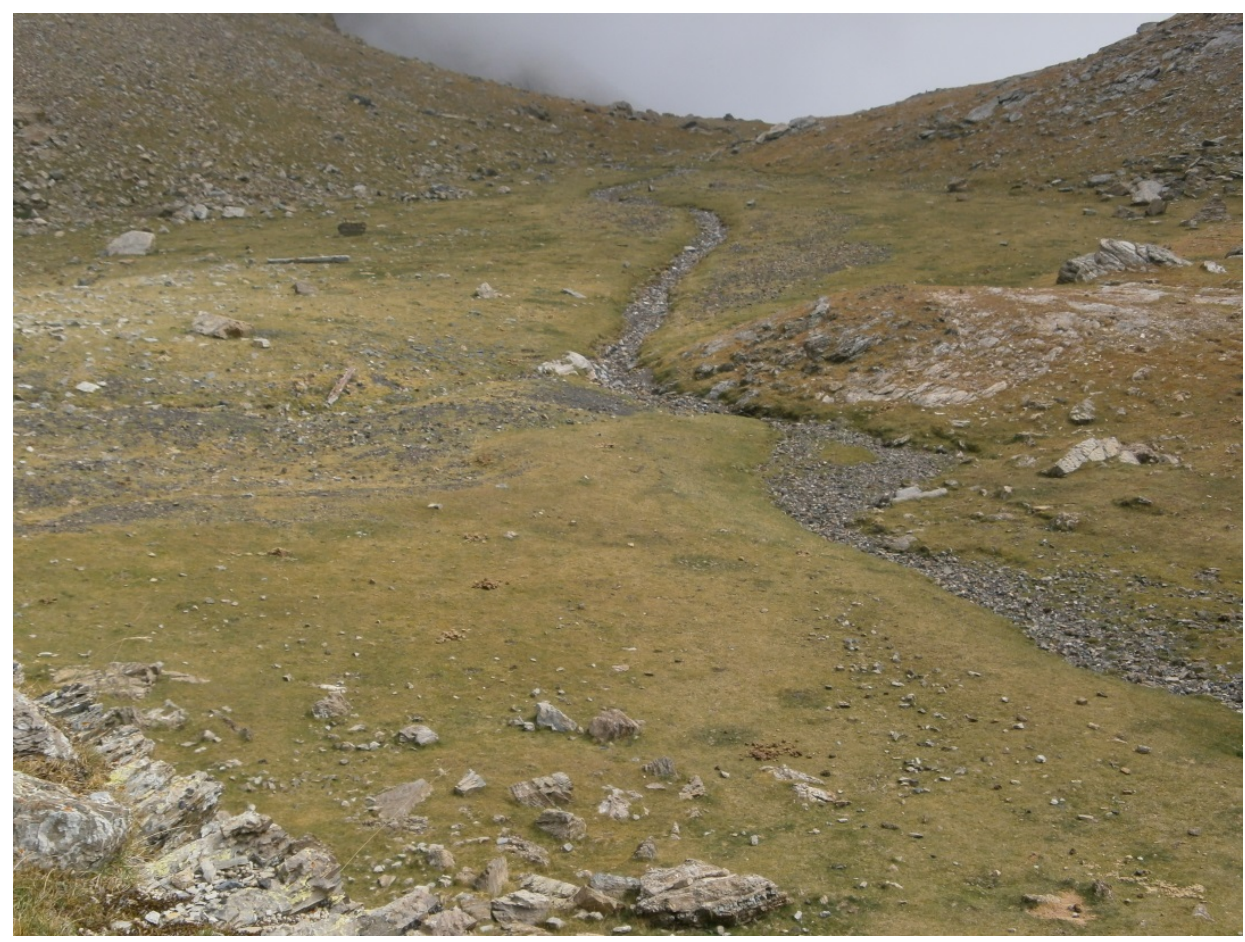

Fotografia 4. La Coma d'Entremonts, que correspon a un antic estany glacial reblert de sediments del Pleistocè i de I'Holocè. Fotografia de l'octubre del 2012.

\subsection{Parada 4. ENCAVALCAMENT D’ENTREMONTS. MONTORROIO ORIENTAL, (Llessui, terme municipal de Sort, comarca del Pallars Sobirà). (Fulls 214 i 54).}

Des de la parada anterior, cal fer un breu recorregut a peu, anant cap a la Mina d'Amiant. Així, després de sobrepassar la Coma d'Entremonts, podem fer una nova aturada, a uns 50 metres i escaig de l'anterior.

En aquest recorregut, haurem trobat I'aflorament d'unes quarsites que pertanyen al Silurià. Per sobre d'aquestes, haurem trobat els nivells de pissarres ampelítiques negres, també del Silurià (fotografia 6). I més amunt es fan ja palesos els materials carbonatats del Devonià, en posició normal.

Tot i així, mirant cap el Nord, d'on es troba l'escombrera de la Mina d'Amiant, veurem com tornen a aparèixer les pissarres negres del Silurià, situant-se per sobre de les calcàries del Devonià. Més amunt, tornem a veure les calcàries del Devonià, situant-se per sobre dels materials del silurià.

És a dir, estem veient una repetició dels materials del Silurià i del Devonià. Es tracta d'un clar encavalcament. (fotografia 6). Mitjançant aquest, els nivells del Silurià (estratigràficament inferiors) encavalquen als del Devonià (estratigràficament superiors). Tanmateix veiem com els materials carbonatats del Devonià es situen a tot arreu per sobre dels del Silurià, en posició 
normal. Tot això es fa clarament palès a les Raspes de Montorroio, per on afloren a la part superior els materials carbonatats del Devonià, els quals constitueixen les "raspes", en un relleu escarpat.

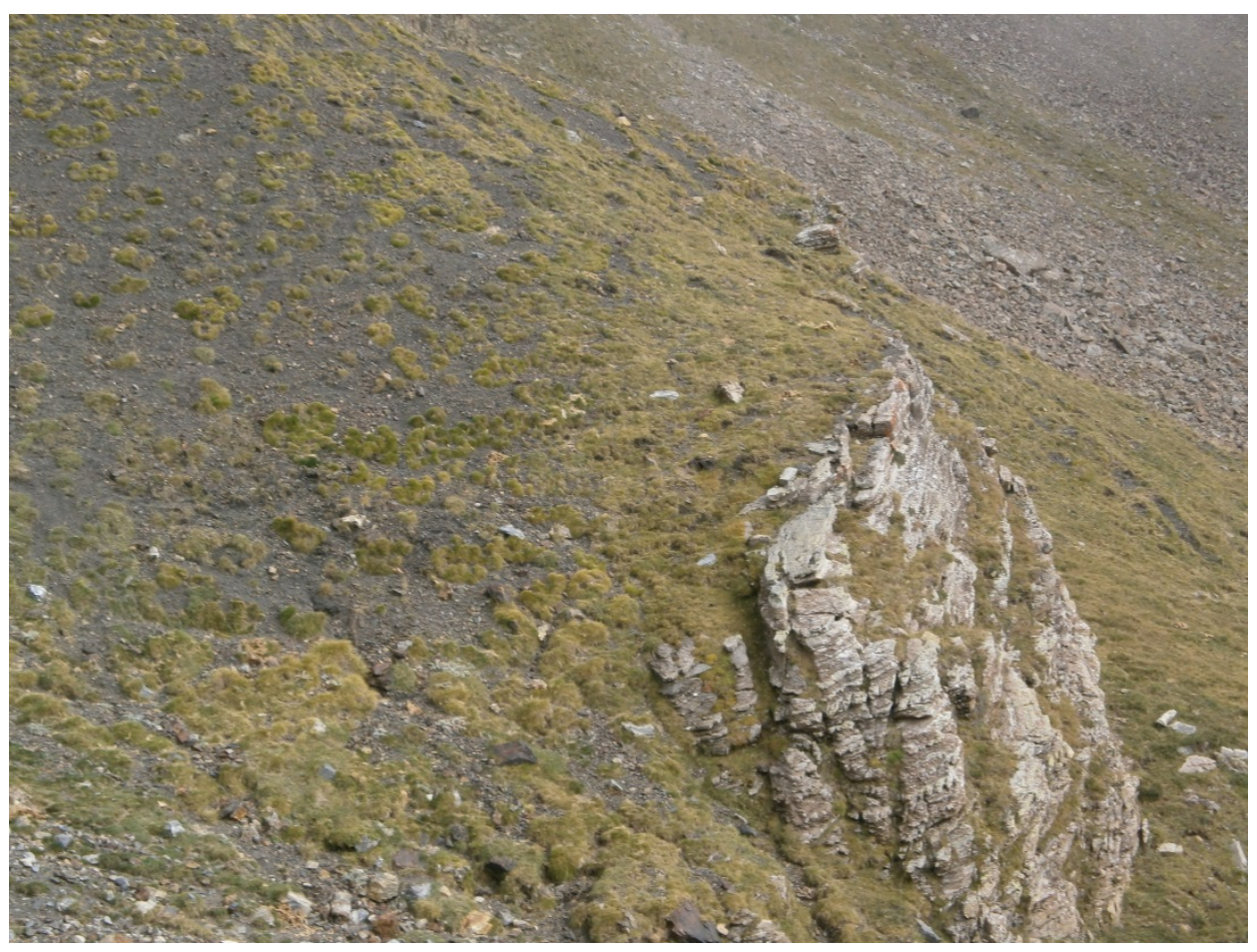

FOTOGRAFIA 5. PARADA 4.

Aflorament de les quarsites i de les pissarres negres del Silurià, per sota de la Mina d'Amiant. Fotografia de l’Octubre del 2013 


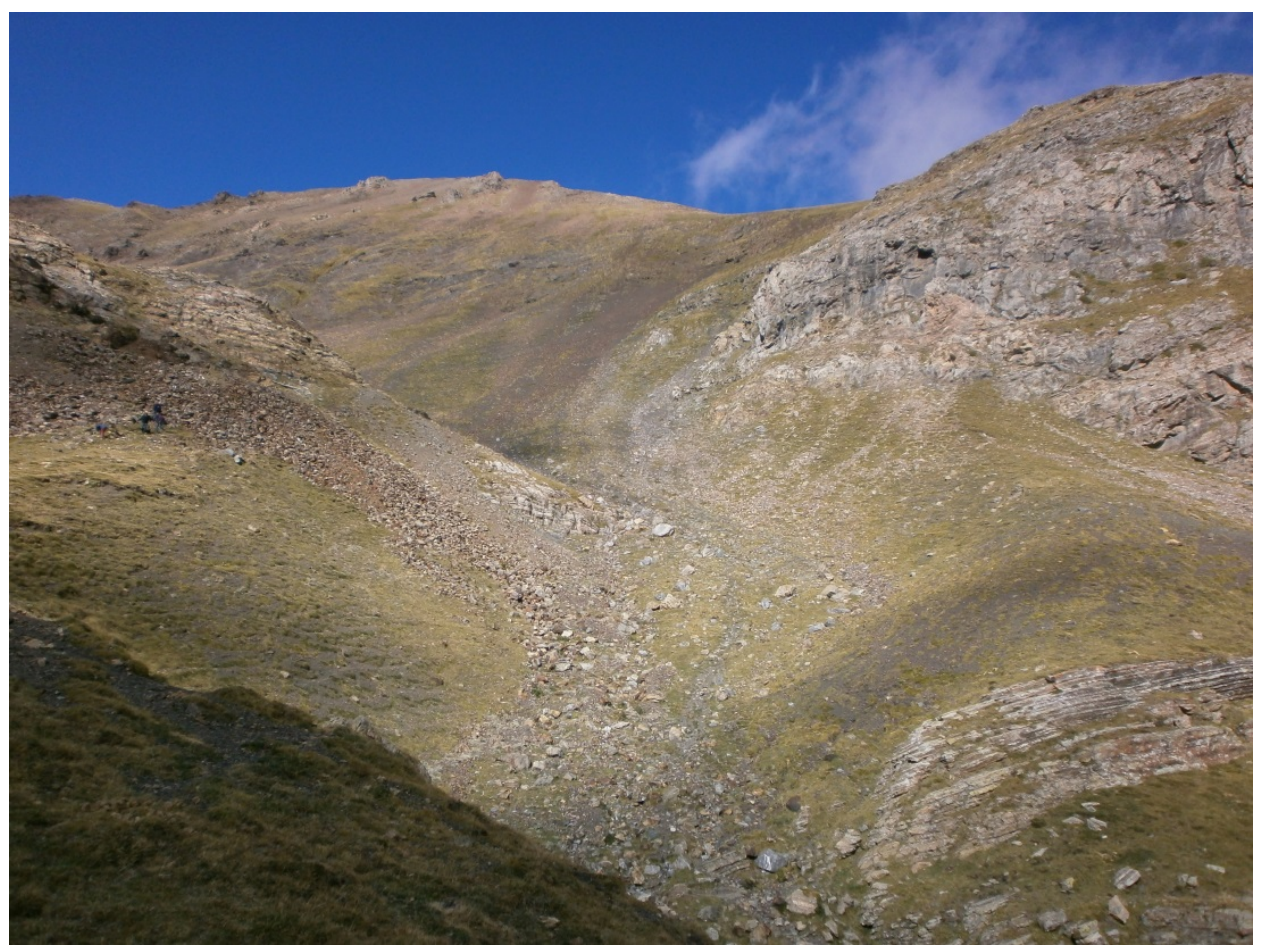

Fotografia 6. Encavalcament d'Entremonts. A la part inferior apareixen les quarsites del Silurià (de color clar). Per sobre hi ha les pissarres del Silurià (de color més fosc, negre, sota l'ombra). Més amunt hi ha els materials carbonats del Devonià (amb tonalitats clars). Sobre d'elles, hi ha les pissarres negres del silurià, encavalcant als anterior. I més amunt els nivells carbonatats del Devonià (a les Raspes). Fotografia d'Octubre del 2013

\subsection{Parada 5. MINA D’AMNIANT D“ENTREMONTS, (Llessui, terme municipal de Sort, comarca del Pallars Sobirà). (Fulls 214 i 54).}

Des de la parada anterior, cal continuar el recorregut cap amunt, per tal d'arribar a la immediata Mina d'Amiant. Així, anirem pujant per l'escombrera i hi arribarem ben ràpidament, a uns 25 - 50 metres de l'anterior aturada.

En aquest recorregut, hem continuat trobant afloraments dels materials paleozoics esmentats a les aturades anteriors. Efectivament, per aquest indret hi afloren les roques carbonatades del Devonià, Tanmateix s'observen afloraments dels nivells pissarrencs del Silurià. Uns i altres materials es troben dintre de la Zona Axial Pirinenca.

En aquest indret, prop del Coll d'Entremonts, va haver-hi una antiga explotació minera, que es troba aturada des de força anys. L'explotació es troba sobre una mineralització associada a skarn, desenvolupada sobre els nivells carbonatats del Devonià. Tot i així, no arriben a aflorar les granodiorites, que són relativament properes. Entre els minerals cal destacar la presencia de la TREMOLITA, la qual es presenta en la seva varietat fibrosa: I'AMIANT, que va ésser el material explotat. Tanmateix hi ha indicis d'ANATASA i d'HEMATITES (molt ben cristal-litzat). (fotografia 7).

Cal dir que en aquest indret no hi ha cap element a ressaltar del Patrimoni Miner; però si del Patrimoni Geològic (pel que fa a la mineralització) i en concret del Patrimoni Mineralògic (per la poca abundor d'aquests tipus de mineralització a Catalunya). Per d'altra banda, cal tenir en 
compte que no es poden extreure mostres minerals, per estar situat dintre d'un Parc Nacional, i també en funció de la conservació del Patrimoni Mineralògic.

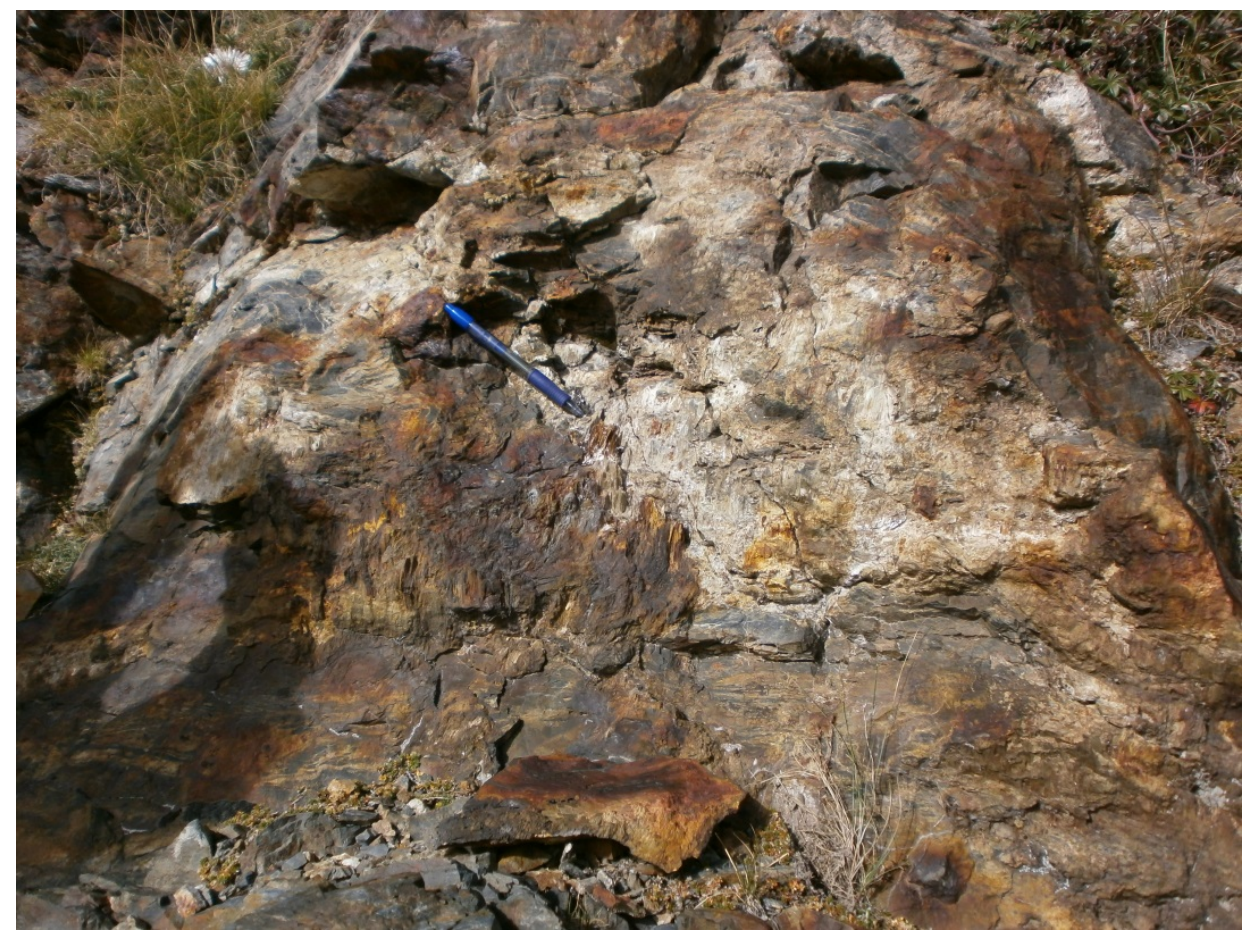

Fotografia 7. Un aspecte de les mineralitzacions fibroses de I'AMIANT (TREMOLITA), de tonalitats blanquinoses. Fotografia de l'Octubre del 2013

\subsection{Parada 6 - CONDICIONAL. MINA DE MANGANÉS DE MONTORROIO, (Llessui, terme municipal de Sort, comarca del Pallars Sobirà). (Fulls 214 i 54).}

Després de la realització de la parada anterior, ens caldrà retornar a la pista, per tal d'efectuar un nou recorregut, anant sempre cap el Nord. Així, ara arribarem als peus del Montorroio. En trobar el barranc del Clot de Montorroio ${ }^{\circ}$, ens convindrà deixar el cotxe de nou, per tal de remuntar el barranc, per tal d'arribar fins a la Mina de Manganès de Montorroio. En arribar-hi, farem una nova aturada, després d'ascendir de nou uns 250 metes i d'haver fet un recorregut per la pista de prop de $1^{\prime} 5 \mathrm{Km}$.

Com als recorreguts anteriors, en aquesta ocasió, hem tornat a trobar afloraments dels materials carbonatats del Devonià. Així, ara haurem vist uns nivells de calcàries rogenques, molt carregades amb òxids de ferro.

Precisament, sobre aquestes calcàries va haver-hi una antiga explotació minera. Es va dedicar a l'aprofitament dels minerals de manganès, situats entre cavitats d'origen kàrstic, reblertes per aquests minerals i també pels de ferro. Així, entre els minerals presents es troben: PIROLUSITA, PSILOMELANA, RAMSDELLITA, TODOROQUITA, MANGANOCALCITA i RODOCROISITA, entre els minerals de manganès. També hi ha GOETHITA, LEMATITES,

Recorregut de recerca geològica i mineralògica per la comarca del Pallars Sobirà: des del Coll de Triador, a Entremonts, al Pas de Mainera, a la Portella i alCcoll d'Eixol 
LEPIDOCRICITA i SIDERITA, entre els minerals ferro. Amb tots ells, també es troba la CALCITA.

Tot i així, malgrat l'abundor dels minerals presents no es poden extreure mostres minerals, per estar situat dintre d'un Parc Nacional.

\subsection{Parada 7. APARCAMENT DE MAINERA, (Llessui, terme municipal de Sort, comarca del Pallars Sobirà). (Fulls 214 i 54).}

Des de la parada anterior, cal continuar cap al Nord, per la pista que es va aproximant cap a la població de Espot. En arribar a l'aparcament de Mainera, ens caldrà deixar el cotxe, per tal de fer un nou recorregut a peu. Tot i així, en aquest indret, farem una nova aturada, a uns $2 \mathrm{Km}$ de I'anteriorment realitzada.

Com als casos anteriors, en aquest recorregut, hem continuat trobant afloraments dels materials paleozoics esmentats a les aturades anteriors. Així, es fan palesos per arreu els nivells carbonats del Devonià, els qual formen part de l'Aureola de contacte. En aquest recorregut, hem anat veients diferents aspectes de la morfologia glacial i periglacial per tot arreu.

\subsection{Parada 8 - CONDICIONAL. INDICIS DE MANGANÉS DEL PAS DE MAINERA, (Llessui, terme municipal de Sort, comarca del Pallars Sobirà). (Fulls 214 i 54).}

Des de la parada anterior, cal anar a peu cap el Nord, per la Vall de la Mainera, remuntant el riuet del mateix nom. Així, anirem pujant per l'esquerra del riu (en sentit descendent del mateix). Poc després d'arribar a la Cabana de la Solana del Tron (d'Altron), ens caldrà fer una nova aturada. Així, haurem efectuat un recorregut aproximat d'uns 200 - 300 metres.

En aquest recorregut, hem anat trobant els materials esmentats a les aturades anteriors. Així, ara aquí es fan paleses les calcàries del Devonià. Aquestes afloren per arreu a l'indret on ara som.

En aquest indret hi ha unes mineralitzacions estratiformes de minerals de manganès. De fet, es tracta d'unes calcaries enriquides amb òxids de manganès. Tot i això, els minerals d'aquest metall no es fan palesos, ja que es tracta d'una substitució parcial del calci dels carbonats per manganès. Així, els minerals que hi trobem són: CALCITA i indicis de MANGANOCALCITA.

Tot i així, no es poden extreure mostres minerals, per estar situat dintre d'un Parc Nacional, a excepció de gaudir d'una autorització del parc, per tal de fer anàlisis de les mostres, si s'escau. 


\subsection{Parada 9. ESFONDRAMENT DE LA PORTELLA, (Llessui, terme de Sort, comarca del Pallars Sobirà). (Fulls 214 i 54).}

Després de fer l'aturada anterior, cal fer un nou recorregut per la pista que va conduint cap a Espot. Així, aviat començarem a pujar cap el Coll de la Portella. Abans, però, ens caldrà fer una nova aturada a uns $2^{\prime} 5 \mathrm{Km}$ de la parada anterior.

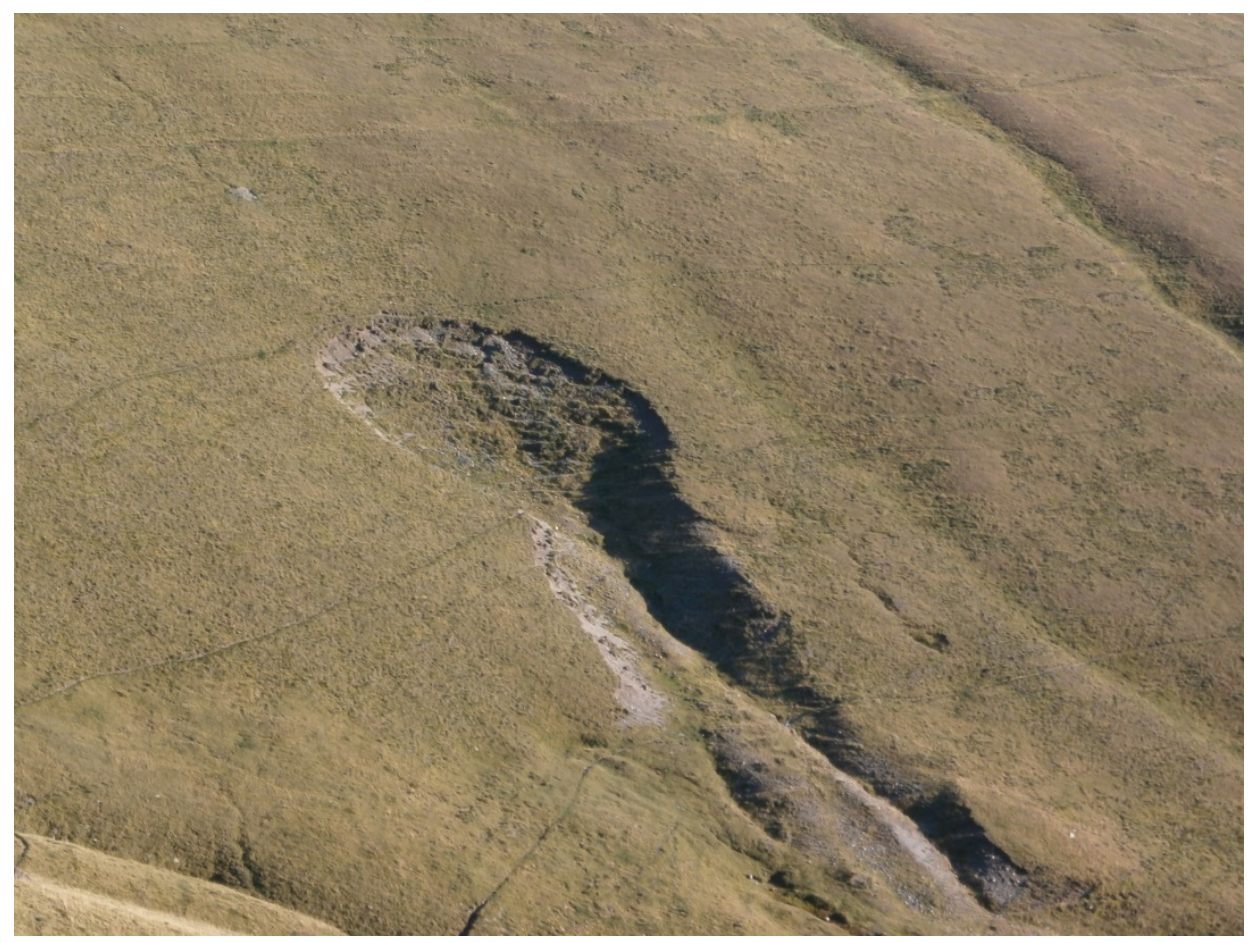

Fotografia 8. Esfondrament en cullera de la Portella. Fotografia d’Octubre del 2013 
En aquest recorregut, anirem remuntant els relleus de la Serravilla, entre afloraments dels materials paleozoics, fonamentalment del Silurià i del Devonià. Tot i així, els primers es fan molt evidents (situant-se a la part baixa), donant lloc, com a conseqüència de la seva plasticitat, a freqüents fenòmens de solifluxió, de desplaçament de vessants. Així, per arreu, en aquest tram del recorregut, es poden veure nombrosos exemples d'aquest tipus de morfologia periglacial. Cal dir que tots aquests materials, encavalquen als esquistos de I'Ordovicià, situats més avall. L'encavalcament es produeix mitjançant la plasticitat dels materials del Silurià. Tanmateix, per sobre d'on som, hi ha un altre encavalcament, el de Serravilla, entre els materials del Devonià

En aquest indret, es pot observar un fenomen típic d'esfondrament en cullera. (fotografia 8).

\subsection{Parada 10. COLL DE LA PORTELLA, (Caregue, terme municipal de Rialp, comarca del Pallars Sobirà). (Fulls 181 i 54)}

Des de la parada anterior, cal continuar, cap el Nord, arribant ara al Colletó de la Portella i cap el Coll de la Portella. Aquí farem una nova aturada a poc menys de 0 ' $5 \mathrm{Km}$ des de l'aturada anteriorment realitzada.

En aquest recorregut, hem anat trobant els materials del Devonià que hem esmentat al recorregut cap a l'aturada anterior, els quals es troben situats sobre els del Silurià. Ara hem arribat molt a prop de l'Encavalcament de Serravilla, situat per sobre nostre, a ponent.

En aquest indret, es pot fer una interessant visió, dels relleus del Pallars Sobirà i de I'Alt Urgell. Així, es ben visible el Cadí, mirant cap a llevant. (fotografia 9).

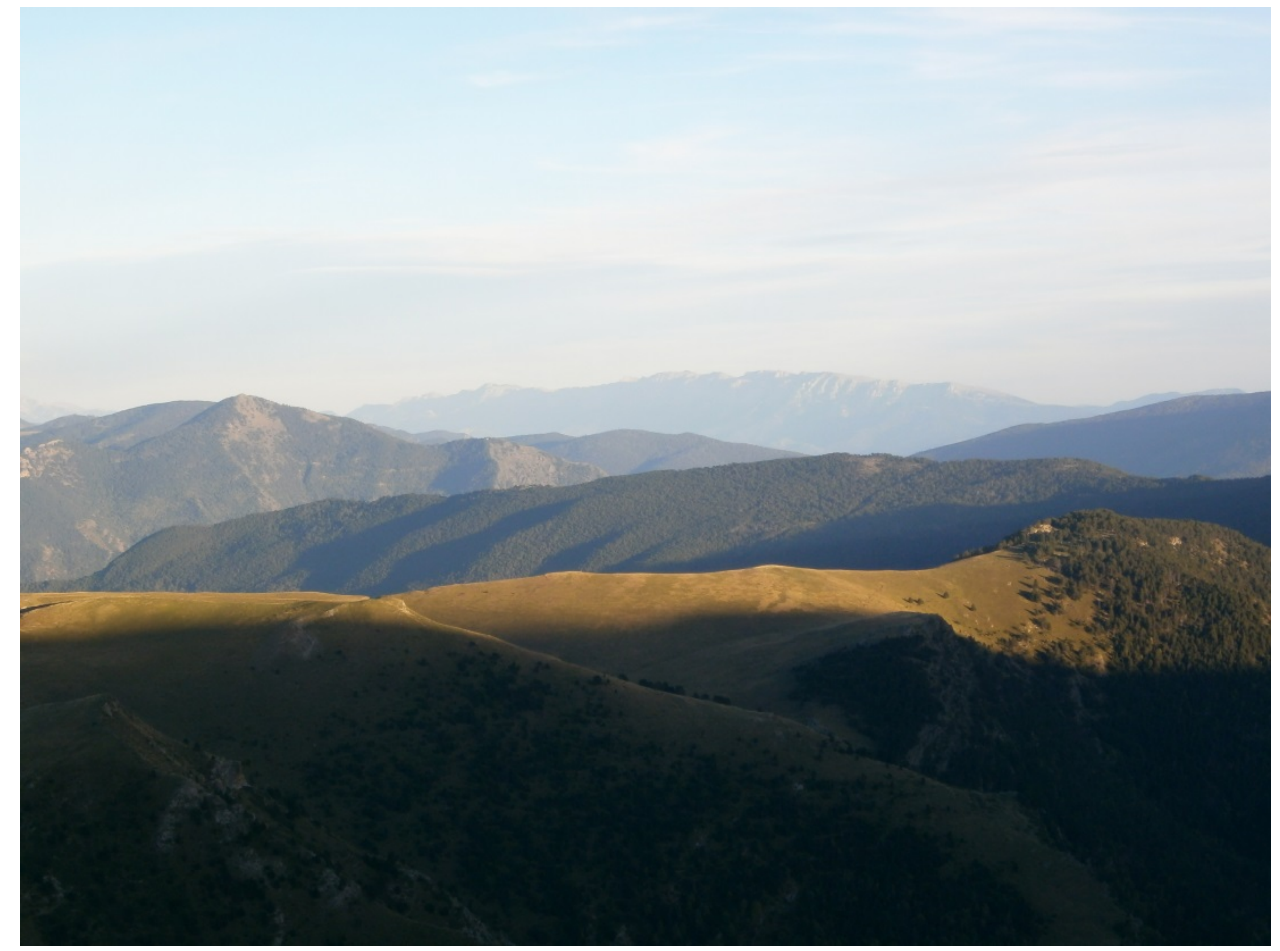

Fotografia 9. El Cadí, des del Coll de la Portella. Fotografia d'Octubre del 2013 
Tanmateix, des d'aquest indret, mirant cap al NE es poden veure els relleus de la Pica d'Estats, del Sotllo i del Monteixo, entre altres indrets del Pallars Sobirà. (fotografía 10)

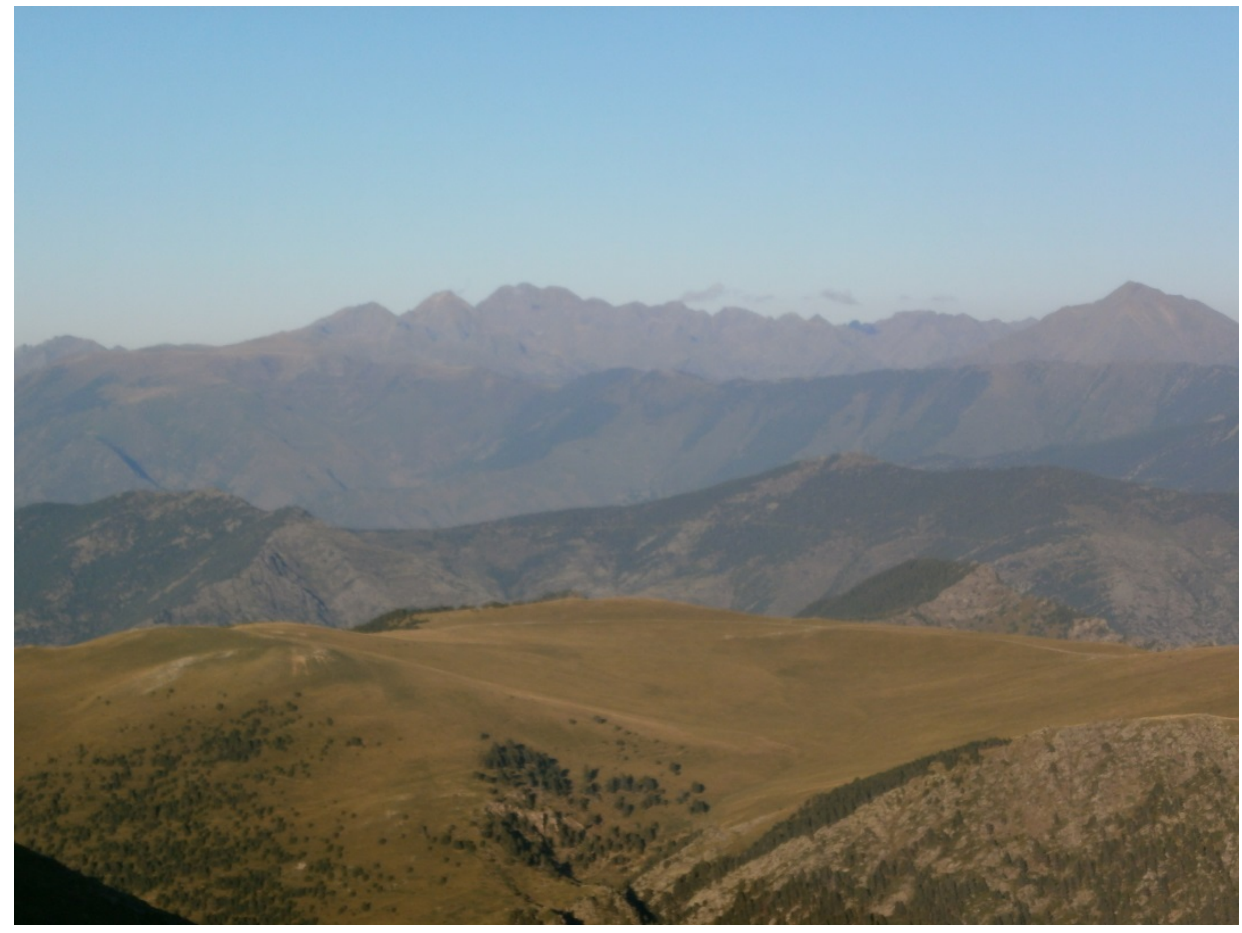

Fotografia 10. La Pica d'Estats (al centre), el Sotllo (a la dreta) i el Monteixo (a l'esquerra), des del Coll de la Portella. Fotografia de l'Octubre del 2013

\subsection{Parada 11. COLLADA DE LA SERRA DELS ESTANYETS. IMMEDIACIONS DE LA FONT BLANCA, (terme municipal d'Espot, comarca del Pallars Sobirà). (Fulls 181 i 54).}

Des de la parada anterior, cal continuar, una vegada més cap el Nord, anant sempre cap a la població d'Espot. En aquest recorregut, haurem deixat per l'esquerra el camí que dirigeix cap a Caregue. Més endavant, arribarem a les immediacions de la Serra dels Estanyets. I poc després a una colladeta, per on podem fer una nova aturada, a uns $3 \mathrm{Km}$ de l'anteriorment realitzada.

En aquest recorregut, anirem trobant afloraments dels materials esmentats a les aturades anteriors, els quals pertanyen al Devonià. Així, haurem vist afloraments dels materials carbonatats. Cal dir, també, que ens continuem trobant situats dintre dels denominats Apilaments Antiformes de la Zona Axial Pirinenca. Estem situats dintre de l'Aureola de Metamorfisme.

En aquest indret, caminant des del camí cap un turó proper, podem fer una observació similar a la de la parada anterior. Així, es fan palesos en la llunyania els relleus del Cadí, de la Pica d'Estats, del Sotllo i del Monteixo, entre altres relleus. També es fa palès en primer terme el 
Barranc de Caregue. Cal dir que aquest neix prop d'on ara som. Concretament a la denominada Font Blanca, visible des de les proximitats d'on ara ens trobem situats. (fotografia 11).

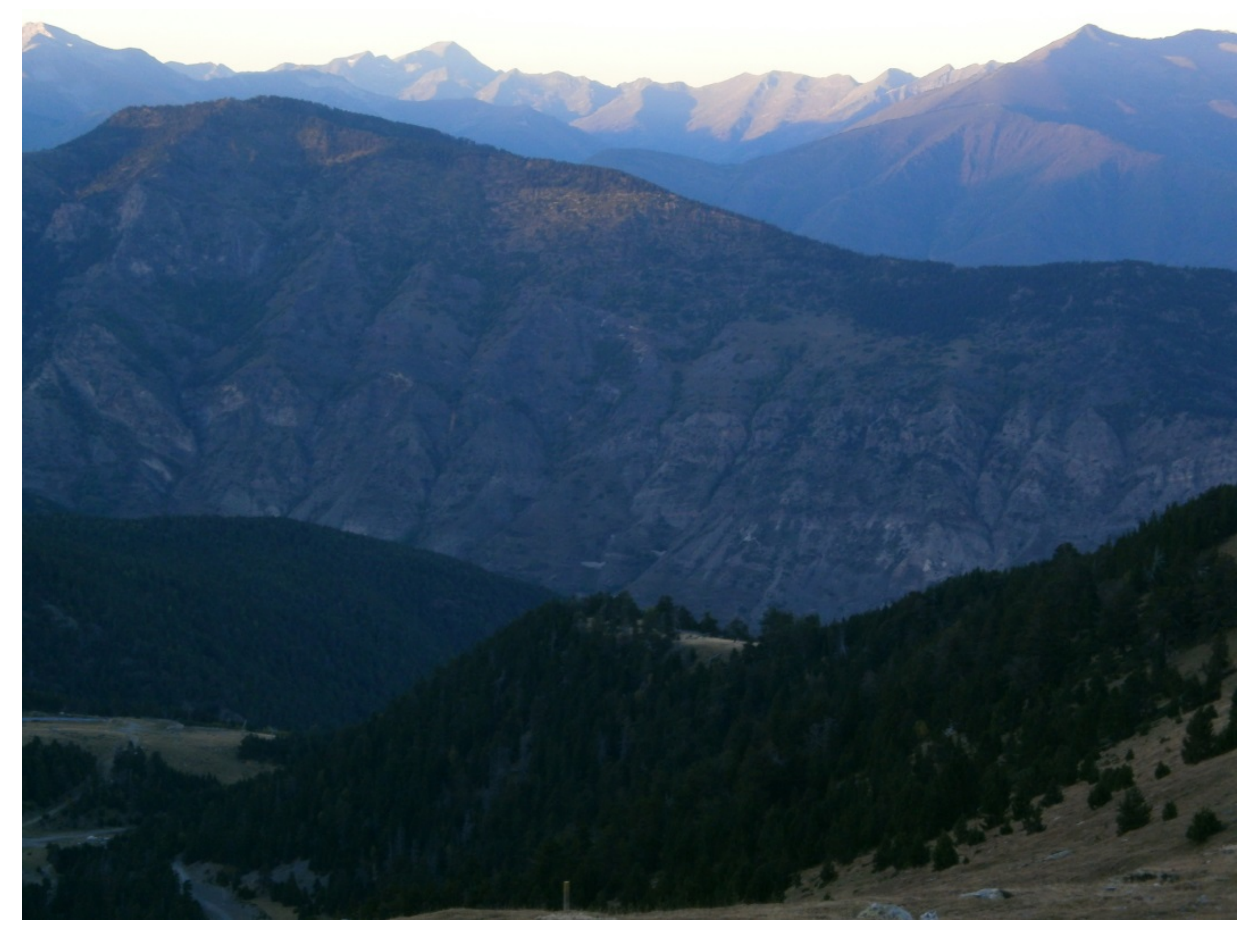

Fotografia 11. Relleus de la Pica d'Estats i del Sotllo, des de la Collada de la Serra dels Estanyets. En primer terme hi ha el Barranc de Caregue. Fotografia del capvespre d’Octubre del 2013

\subsection{Parada 12. COLL D’EIXOL, (terme municipal de Espot, comarca del Pallars Sobirà). (Fulls 214 i 54).}

Des de la parada anterior, cal continuar, una vegada més cap el Nord, anant sempre cap a la població d'Espot. En aquest recorregut, haurem deixat per l'esquerra el camí que dirigeix cap a Escart i cap a Baiesca. Més endavant, arribarem al Cap de la Socarrada, des d'on podem fer un petit desplaçament, per tal d'anar cap el Coll d'Eixol. Aquí, podem fer una nova aturada, a uns $2 \mathrm{Km}$ de la parada anterior, després de sobrepassar el Refugi Forestal de Quatrepins i el mateix coll.

En aquest recorregut, hem continuat trobant els materials esmentats a les aturades anteriors. És a dir: ens continuem trobant dintre de l'aureola de metamorfisme, i haurem vist els nivells de les calcàries i pissarres del Devonià. Aquests són els materials que apareixen a l'indret de I'aturada.

També, en aquest recorregut, haurem trobat bons exemples de geomorfologia glacial i periglacial, per tot arreu. Així, cal dir que des de les immediacions del coll es pot gaudir d'una bona visió (en dies clars) d'una bona part del Pallars Sobirà i del conjunt dels Pirineus, similar a la de les parades anteriors. Així es poden veure eles relleus de la Pica d'Estats i del Sotllo, 
entre altres indrets. També, es pot veure el relleu glacial del riu Escrita, que discorre prop d’Espot. (fotografia 12).

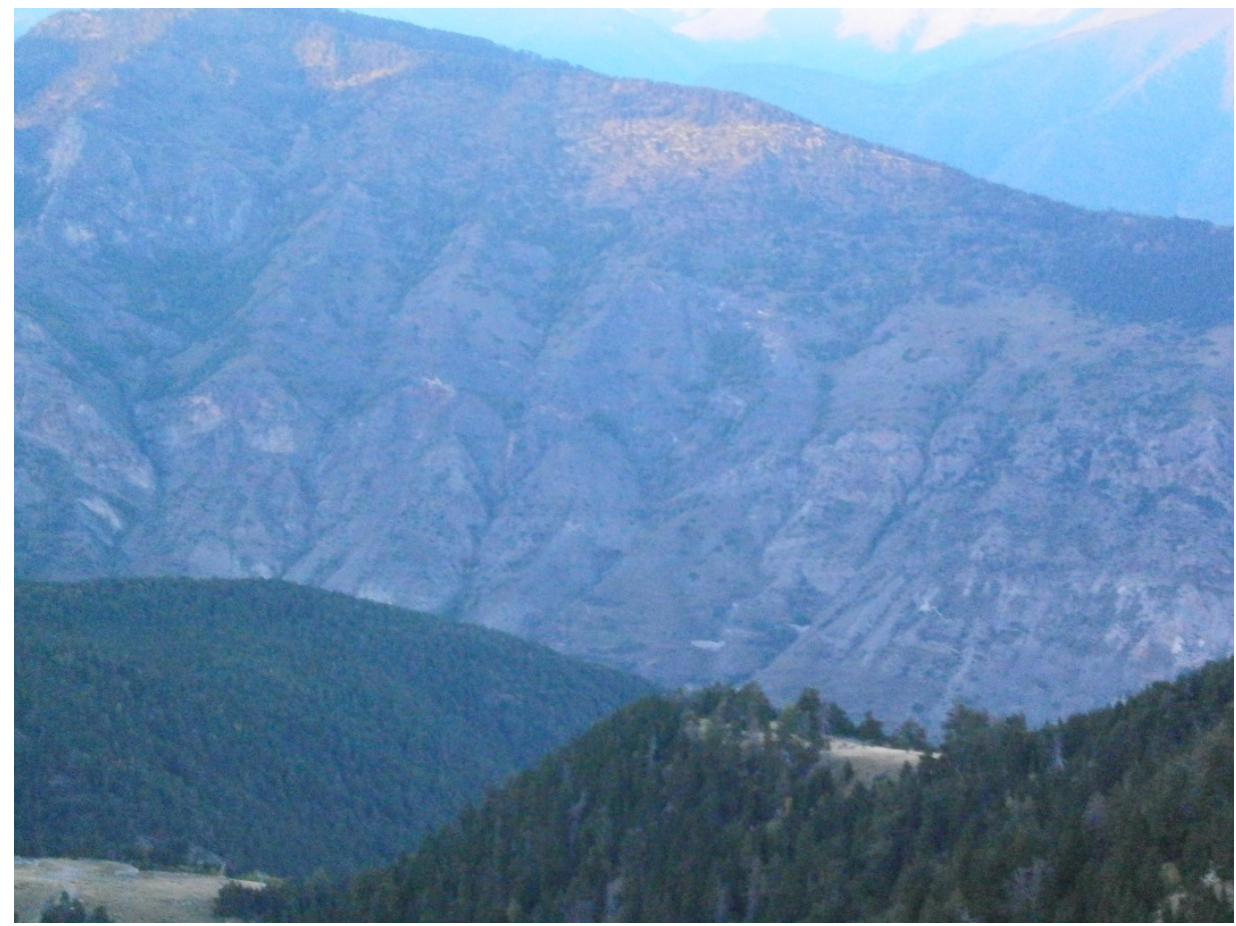

Fotografia 12. La Vall glacial del riu Escrita, des de les immediacions del Coll d'Eixol. Fotografia d'Octubre del 2013

En aquest indret finalitza el recorregut de l'itinerari. 


\section{Bibliografia}

GUIMERÀ, J. et altri (1992).- Geologia (II), Història Natural dels Països Catalans, Vol. 2, 547 pag. Enciclopèdia Catalana, S.A. Barcelona.

MARTínEZ RIUS, A. Et altri (2013).- Guia Geològica del Parc Natural d'Aigüestortes i Estany de Sant Maurici. Publicada a Guies Geològiques dels Parcs Nacionals (dirigida per Roberto Rodríguez Fernández). IGME -Edit Everest. 225 pàgines. Madrid.

MATA-PERELLÓ, J.M. (1991).- Els Minerals de Catalunya. Arxius de la Secció de Ciències de I'Institut d'Estudis Catalans, vol.47, 545 pàgines. Barcelona.

MATA-PERELLÓ, J.M. (2013a).- Recorregut de recerca geològica i mineralògica per la comarca del Pallars Jussà: des de Senterada, a la Pobleta de Bellveí, a la Plana de Mont-ros, a Cabdella i a Sallente. Inèdit. 14 pàgines. Manresa.

MATA-PERELLÓ, J.M. (2013b).- Recorregut de recerca geològica i mineralògica per la comarca del Pallars Jussà: des de la Torre de Cabdella cap a Cabdella, Sallente i cap I’Estany Gento. Inèdit. 12 pàgines. Manresa.

MATA-PERELLÓ, J.M. (2013c).- Recorregut de recerca geològica i mineralògica per la comarca del Pallars Jussà: des d'Espui, cap al Coll de Triador, I'Estany Gento, I'Estany Tort i cap a Colomina. Inèdit. 14 pàgines. Manresa.

MATA-PERELLÓ, J.M. (2013d).- Apunts per a un recorregut de recerca geològica i mineralògica per la comarca del Pallars Sobirà: des de Llessui al Coll de Triador, a Entremonts, als Estanys de Mainera i a Espot. Inèdit. 10 pàgines. Manresa.

MATA-PERELLÓ, J.M. i SANZ BALAGUÉ, J. (1993).- Guía de identificación de Minerales, adaptada fundamentalmente a la Península Ibérica. Parcir, Edic. Selectas, 243 pàgines. Manresa.

RIBA ARDERIU, O. et altri (1976).- Geografia Física dels Països Catalans. Edit Ketres. 211 pàgines. Barcelona. 